\title{
PELAKSANAAN PERATURAN DAERAH NOMOR 11 TAHUN 2008 TENTANG ALOKASI DANA DESA DI KECAMATAN LIBURENG KABUPATEN BONE
}

\author{
Oleh: \\ ANDI KASMAWATI \\ MELINDAH \\ Dosen PPKn Fakultas Ilmu Sosial UNM
}

\begin{abstract}
ABSTRAK: Penelitian ini bertujuan untuk mengetahui (1) Pelaksanaan Peraturan Daerah Nomor 11 Tahun 2008 Tentang Alokasi Dana Desa Di Kecamatan Libureng Kabupaten Bone. (2) Hambatan Dalam Pelaksanaan Peraturan Daerah Nomor 11 Tahun 2008 Tentang Alokasi Dana Desa Di Kecamatan Libureng Kabupaten Bone. Untuk mencapai tujuan tersebut maka peneliti menggunakan teknik pengumpulan data melalui wawancara dan dokumentasi. Jenis penelitian ini adalah penelitian deskriptif kualitatif. Sumber Data yang digunakan terdiri dari data primer dan data sekunder. Data yang telah diperoleh dari hasil penelitian diolah dengan menggunakan analisis kualitatif untuk mengetahui Pelaksanaan Peraturan Daerah Nomor 11 Tahun 2008 Tentang Alokasi Dana Desa Di Kecamatan Libureng Kabupaten Bone, dan Hambatan dalam Pelaksanaan Peraturan Daerah Nomor 11 Tahun 2008 Tentang Alokasi Dana Desa Di Kecamatan Libureng Kabupaten Bone. Hasil penelitian menunjukkan bahwa: (1) Pelaksanaan Peraturan Daerah Nomor 11 tahun 2008 tentang Alokasi Dana Desa (ADD) di Kecamatan Libureng Kabupaten Bone berjalan cukup Baik. Hal ini dapat terlihat dari tahap perencanaan berupa aparat Pemerintahan telah melakukan musyawarah dalam hal perencanaan $\mathrm{ADD}$, dan melakukan pembuatan RPJMDes, serta pembuatan RKPDes Sebagaimana Peraturan daerah tentang ADD yang dapat menjadi arahan bagi Tim Pelaksana Desa dalam menjalankan ADD baik dalam hal pengalokasian dana serta tujuan penggunaan dana. (2) Beberapa hambatan dalam pelaksanaan ADD yang ditemui yakni pembuatan laporan pertanggungjawaban dan kondisi cuaca di lingkungan desa seperti musim hujan yang dapat menghambat pelaksanaan pembangunan yang dilakukan. Setiap permasalahan yang mereka dapatkan dalam proses pelaksanaan ADD di Desanya dapat di selesaikannya dengan adanya bimbingan dan konsultasi dengan pihal-pihak yang terkait seperti tim Pembina tingkat kabupaten dan tim Pembina tingkat kecamatan.
\end{abstract}

\section{Kata Kunci: Alokasi Dana Desa}

ABSTRACT: This study aims to determine (1) Implementation of Regional Regulation No. 11 of 2008 on the Village Fund Allocation In District Libureng Bone regency. (2) Barriers in Implementing Regional Regulation No. 11 of 2008 on the Village Fund Allocation In District Libureng Bone regency. To achieve these objectives, the researchers used a technique of collecting data through interviews and documentation. This research is a qualitative descriptive study. Sources of data used consist of primary data and secondary data. Data have been obtained from the results of the study were processed using qualitative analysis to determine Implementation of Regional Regulation No. 11 of 2008 on the Village Fund Allocation In District Libureng Bone regency, and Barriers in the Implementation of Regional Regulation No. 11 of 2008 on the Village Fund Allocation In District Libureng Bone District, The results showed that: (1) Implementation of Regional Regulation No. 11 of 2008 concerning Village Allocation Fund (ADD) in District Libureng Bone regency runs quite Good. It can be seen from the planning stage in the form of personnel administration has to be consulted in planning 
ADD, and do manufacture RPJMDes, as well as the manufacture RKPDes As local regulation of ADD can be a direction to the Executive Team Village in running ADD both in terms of allocation of funds and purpose of use fund. (2) Some of the obstacles encountered in the implementation ADD ie reporting of accountability and weather conditions in the village as the rainy season may hamper the implementation of the development undertaken. Every problem that they get in the process of implementation of ADD in his village can selesaikannya with their guidance and consultation with pihalparties, such as team Pembina Pembina district and sub-district level teams.

\section{Keywords: Village Fund Allocation}

\section{PENDAHULUAN}

Negara Republik Indonesia sebagai Negara Kesatuan menganut asas desentralisasi dalam menyelenggarakan pemerintahan dengan memberikan kesempatan dan keleluasaan kepada daerah untuk menyelenggarakan otonomi daerah. Dalam Pasal 18 Undang-Undang Dasar 1945 diatur bahwa, Pembagian daerah Indonesia atas daerah besar dan kecil, dengan susunan pemerintahannya ditetapkan dengan undang-undang, dengan memandang dan mengingat dasar permusyawaratan dalam sistem pemerintahan Negara, dan hak asal-usul dalam daerah-daerah yang bersifat istimewa. Daerah di Indonesia akan dibagi menjadi daerah Provinsi, Kabupaten, Kecamatan Dan Desa. Dalam konteks ini, pemerintahan desa adalah merupakan sub sistem dari sistem penyelenggaraan pemerintahan nasional yang langsung berada di bawah pemerintah kabupaten.

Tujuan utama penyelenggaraan otonomi daerah adalah untuk meningkatkan pelayanan publik dan meningkatkan perekonomian daerah. Pada dasarnya, terkandung tiga misi utama pelaksanaan otonomi daerah dan desentralisasi fiscal, yaitu meningkatkan kualitas dan kuantitas pelayanan publik kepada masyarakat, menciptakan efisiensi dan efektifitas pengolalan sumber daya daerah, dan memberdayakan serta menciptakan ruang bagi masyarakat untuk berpartisipasi dalam pembangunan. Keberadaan Desa secara yuridis formal diakui dalam Undang-undang Nomor 32
Tahun 2004 tentang Pemerintahan Daerah dan Peraturan Pemerintah Nomor 72 Tahun 2005 tentang Desa. Berdasarkan ketentuan ini Desa diberi pengertian sebagai kesatuan masyarakat hukum yang memiliki batas-batas wilayah yang berwenang untuk mengatur dan mengurus kepentingan masyarakat setempat, berdasarkan asal-usul dan adat istiadat setempat yang diakui dan dihormati dalam sistem Pemerintahan Negara Kesatuan Republik Indonesia.

Penyelenggaraan Pemerintahan Desa tidak terpisahkan dari penyelenggaraan otonomi daerah. Pemerintahan Desa merupakan unit terdepan (ujung tombak) dalam pelayanan kepada masyarakat serta menjadi tonggak strategis untuk keberhasilan semua program yang dijalankan pemerintah. Karena itu upaya untuk memperkuat Desa (pemerintahan Desa dan lembaga kemasyarakatan Desa) merupakan langkah untuk mempercepat terwujudnya kesejahteraan masyarakat sebagai hakikat dari otonomi daerah.

Pemahaman Desa di atas menempatkan Desa sebagai suatu organisasi pemerintahan yang secara politis memiliki kewenangan tertentu untuk mengurus dan mengatur warga atau komunitasnya. Dengan posisi tersebut desa memiliki peran yang sangat penting dalam menunjang kesuksesan Pemerintahan Nasional secara luas.

Dengan demikian, dalam pengaturan pemerintahan Desa telah mengalami perbedaan sudut pandang utama dalam hal kewenangan. Pemerintah 
Pusat dan Pemerintah Daerah sebagaimana dimaklumi tidak lagi campur tangan secara langsung tetapi memberikan pedoman, bimbingan, pelatihan dan pembelajaran kepada pemerintahan Desa dalam melaksanakan fungsi, tugas, dan wewenangnya.

Dalam ketentuan umum Peraturan Pemerintah Nomor 72 Tahun 2005 telah dijelaskan tentang defenisi dari Alokasi Dana Desa. Dimana yang dimaksud dengan Alokasi Dana Desa adalah dana yang dialokasikan oleh pemerintah Kabupaten/Kota untuk desa yang bersumber dari dana perimbangan keuangan pemerintah pusat dan daerah bagi pemerintah Kabupaten/Kota.

Untuk melaksanakan hal tersebut

Pemerintah Daerah Kabupaten Bone membentuk Peraturan Daerah Nomor 11 Tahun 2008 tentang Alokasi Dana Desa, dalam hal tujuan, sumber dan proporsi Alokasi Dana Desa dimana dalam pasal 2 ayat 1 mengatur tujuan Alokasi Dana Desa yakni untuk pemerataan pembangunan dan meningkatkan partisipasi, kesejahteraan serta pelayanan masyarakat desa melalui pembangunan dalam skala desa. Dimana hal tersebut diperjelas pada ayat 3 bahwa pembagian alokasi dana desa untuk setiap desa secara proporsional.

Ketentuan pasal tersebut mengamanatkan kepada Pemerintah Kabupaten untuk mengalokasikan dana perimbangan yang diterima Kabupaten kepada Desa-desa dengan memperhatikan prinsip keadilan dan menjamin adanya pemerataan.

Alasan peneliti memilih Alokasi Dana Desa sebagai bahan penelitian dikarenakan Alokasi Dana Desa mempunyai pengaruh yang besar dalam pembangunan Desa dibandingkan dengan sumber-sumber dana pendapatan Desa yang lain. Apabila Alokasi Dana Desa benar-benar dikelola dengan baik dan jujur maka bukan tidak mungkin program ini akan meningkatkan pelayanan publik di pedesaan, partisipasi masyarakat dalam pembangunan akan meningkat, dan tentu saja akan bermuara pada kesejahteraan masyarakat Desa.

Peraturan Daerah Nomor 11 Tahun 2008 pada prinsipnya menginginkan agar semua pihak yang bersangkutan dapat melaksanakannya. Namun pada pelaksanaannya sejak diterbitkannya perda tersebut tidak berkesesuaian antara aturan perda dengan pelaksanaannya. Maka dalam hal ini penulis mengankat sebuah judul : "Pelaksanaan Peraturan Daerah Nomor 11 Tahun 2008 tentang Alokasi Dana Desa di Kecamatan Libureng Kabupaten Bone".

\section{TINJAUAN PUSTAKA}

Secara umum istilah implementasi dalam Kamus Besar Bahasa Indonesia berarti pelaksaan atau penerapan. Istilah implementasi biasanya dikaitkan dengan suatu kegiatan yang dilaksanakan untuk mencapai tujuan tertentu.Kamus Webster, merumuskan bahwa to implement (mengimplementasikan) berarti to provide the means for carryingout (menyediakan sarana untuk melaksanakan sesuatu), to give practicia effect to (menimbulkan dampak atau akibat terhadap sesuatu). Pengertian tersebut mempunyai arti bahwa untuk mengimplementasikan sesuatu harus disertakan sarana yang mendukung yang nantinya akan menimbulkan dampak atau akibat terhadap sesuatu itu.

Pengertian Implementasi yang dikemukakan oleh Budi Winarto menyatakan bahwa implementasi kebijakan dibatasi sebagai menjangkau tindakan-tindakan yang dilakukan oleh individu-individu pemerintah dan individu-individu swasta (kelompokkelompok) yang diarahkan untuk mencapai tujuan-tujuan yang telah ditetapkan dalam keputusan-keputusan sebelumnya. ${ }^{39}$

\footnotetext{
${ }^{39}$ Budi Winarno,Teori dan Proses Kebijakan

public, Yokyakarta,Media Pressindo 2002,hal 10.
} 
Implementasi menurut Daniel A. Mazmanian dan Paul Sabatier (1979) sebagaimana dikutip dalam buku Solihin Abdul Wahab, mengatakan bahwa: "Implementasi adalah memahami apa yang senyatanya terjadi sesudah suatu program dinyatakan berlaku atau dirumuskan merupakan fokus perhatian implementasi kebijaksanaan yakni kejadian-kejadian dan kegiatan-kegiatan yang timbul sesudah disahkannya pedoman-pedoman kebijaksanaan negara, yang mencakup baik usaha-usaha untuk mengadministrasikannya maupun untuk menimbulkan akibat/dampak nyata pada masyarakat atas kejadian-kejadian". ${ }^{40}$

Dari Pandangan kedua ahli diatas dapat dikatakan bahwa suatu proses implementasi kebijaksanaan itu sesungguhnya tidak hanya menyangkut perilaku badan-badan administratif yang bertanggung jawab melaksanakan suatu program yang telah ditetapkan serta menimbulkan ketaatan pada diri kelompok sasaran, melainkan pula menyangkut jaringan kekuatan-kekuatan politik,ekonomi,dan sosial yang secara langsung maupun tidak langsung dapat mempengaruhi segala pihak yang terlibat,sekalipun dalam hal ini dampak yang diharapkan ataupun yang tidak diharapkan.

\section{Otonomi Daerah}

Secara etimologis, otonomi atau autonomi berasal dari bahasa yunani yaitu „auto ${ }^{\text {ee }}$ yang berarti sendiri dan „nomo yang berarti hukum hukum atau peraturan. Otonomi juga dapat berarti sebagai pengundangan sendiri. Mengatur atau memerintahkan sendiri atau pemerintahan sendiri. Sedangkan daerah adalah suatu wilayah atau lingkungan pemerintahan.
Bagir Manan menyatakan bahwa Otonomi mengandung arti kemandirian untuk mengatur dan mengurus urusan (rumah tangganya) sendiri. ${ }^{41}$

Dalam sebuah literature belanda, otonomi daerah adalah kebebasan dan kemandirian (vrijheid en zelfstandigheid) untuk mengatur dan mengurus sebagian urusan pemerintahan. Kebebasan dan kemandirian dalam hal ini mengandung arti "atas nama dan tanggung jawab sendiri" (op eigen naam en verantwoordelijkheid) menurut M.C. Burkens. ${ }^{42}$

Menurut Murtir jeddawi Otonomi Daerah adalah wewenang daerah untuk mengatur dan mengurus kepentingan masyarakat setempat sesuai prakarsa sendiri berdasarkan aspirasi masyarakat dan batas wewenang yang diberikan pemerintah sesuai peraturan perundangundangan yang berlaku. ${ }^{43}$

Jadi otonomi daerah yaitu hak, wewenang, dan kewajiban daerah otonom untuk mengatur dan mengurus sendiri urusan pemerintahan dan kepentingan masyarakat setempat sesuai dengan peraturan perundang-undangan. Pelaksanaan otonomi daerah dipengaruhi oleh faktor-faktor yang meliputi kemampuan orang/badan yang menjadi pelaksana, kemampuan dalam keuangan, ketersediaan alat dan bahan, dan kemampuan dalam berorganisasi.

\section{Pemerintahan Daerah}

Pemerintahan Daerah adalah pelaksana fungsi-fungsi pemerintahan daerah yang dilakukan oleh lembaga Pemerintahan Daerah yaitu pemerintah daerah dan Dewan Perwakilan Rakyat daerah.

Dalam Pasal 1 angka (3) Undangundang 32 Tahun 2004 tentang Pemerintahan Daerah ditegaskan bahwa

\footnotetext{
42 Ridwan, Hukum Administrasi Di Daerah, Yogyakarta, Fh Uii Pers, 2009, Hal. 26.

${ }^{43}$ Murtir Jeddawi, Hukum Pemerintahan Daerah,

Yogyakarta, Uii Pers, 2006, Hal. 48.

${ }^{40}$ Solihin Abdul Wahab,Analisis Kebijaksanaan : dari formulasi ke implementasi kebijaksanaan negara,Jakarta,Bumi Aksara,2008,hal.65

${ }^{41}$ Azam Awang, Implementasi Pemberdayaan Pemerintah
}

Desa, Yogyakarta, Pustaka Pelajar, 2010, Hal. 52 
Pemerintahan Daerah adalah Gubernur, Bupati atau Walikota dari perangkat daerah sebagai unsur penyelenggaraan pemerintahan daerah" Kepala daerah dan wakilnya dipilh secara langsung oleh rakyat yang persyaratan dan tata caranya telah ditetapkan oleh Undang-undang. Dalam penyelanggaran pemerintahan daerah kepala daerah dibantu perangkat daerah yang terdiri dari sekertaris daerah, sekertariat DPRD, dinas daerah dan lembaga teknis daerah dan khusus untuk daerah kabupaten/kota ditambahan dengan kecamatan dan desa/kelurahan. ${ }^{44}$

Gubernur sebagai kepala daerah propinsi berfungsi pula selaku wakil pemerintah daerah dalam arti untuk menjembatangi dan memperpendek rentang kendali.

\section{Peraturan Daerah}

Peraturan daerah merupakan kebijakan umum pada tingkat daerah yang dihasilkan oleh lembaga eksekutif dan lembaga legislatif sebagai pelaksanaan asaz desentralisasi dalam rangka mengatur dan mengurus rumaha tangga daerah.

Menurut Jimly Asshiddiqie Peraturan Daerah adalah salah satu bentuk peraturan pelaksana undang-undang. Pada pokoknya, kewenangannya mengatur bersumber dari kewenangan yang ditentukan oleh pembentuk undangundang. Akan tetapi, dal hal-hal tertentu, peraturan daerah juga dapat mengatur sendiri hal-hal yang meskipun tidak didelegasikan secara eksplisit kewenangannya oleh undang-undang tetapi dianggap perlu diatur oleh daerah untuk melaksanakan otonomi daerah yang seluas-luasnya sebagaimana dimaksud oleh pasal 18 ayat (3) dan (4) UUD 1945." 45

Peraturan daerah juga dapat diartikan sebagai naskah dinas yang berbentuk peraturan perundang-undangan, yang mengatur urusan otonomi daerah dan tugas pembantuan atau untuk mewujudkan kebijaksanaan baru, melaksankan peraturan perundang-undangan yang lebih tinggi dan menetapkan suatu organisasi dalam pemerintahan daerah yang ditetapkan oleh kepala daerah dengan persetujuan Dewan Perwakilan Rakyat Daerah. Dengan kata lain Peraturan Daerah merupakan produk hukum dari Pemerintahan Daerah dalam rangka penyelenggaraan otonomi daerah dan penjabaran lebih lanjut dari Undangundang yang lebih tinggi yang dibuat dan berlaku di daerah otonom yang bersangkutan.

Menurut Undang-undang Nomor 10 Tahun 2004 tentang pembentukan Peraturan perundang-undangan yang dibentuk oleh Dewan Perwakilan Rakyat Daerah dengan persetujuan bersama kepala daerah, Peraturan daerah tidak boleh bertentangan dengan kepentingan umum maupun peraturan daerah lainnya.

\section{Keuangan Daerah}

Salah satu ukuran keberhasilan suatu daerah otonom dapat dilihat dari kemampuan dalam pengelolaan keuangan daerah. Pengelolaan keuangan daerah yang baik akan bermuara pada peningkatann pendapatan asli daerah dan meningkatkan usaha-usaha pembangunan. Dalam hal ini yang dimaksud dengan keuangan daerah adalah Semua hak dan kewajiban daerah yang dapat dinilai dengan uang dan segala sesuatu berupa uang dan barang yang dapat dijadikan milik daerah yang berhubungan dengan pelaksanaan hak dan kewajiban tersebut. ${ }^{46}$

Pengelolaan keungan daerah telah mengalami berbagai macam penyempurnaan secara konstitusi dimana telah tertuang secara resmi dalam Undangundang Nomor 25 Tahun 1999 dan dilengkapi dengan Undang-undang 34 Tahun 2000. Saat ini, peraturan tersebut

\footnotetext{
${ }^{46}$ Rozali Abdullah, Pelaksanaan Otonomi Luas: Dengan

Pemilihan Kepala Daerah Secara Langsung, Jakarta, Rajawali Pers, 2011, Hal. 143.
}

\footnotetext{
${ }^{44}$ Ibid

${ }^{45}$ Jimly Asshiddiqie, Perihal Undang-Undang, Jakarta, Rajawali Pers, 2010, Hal. 190.
} 
telah disempurnakan dalam Undangundang 32 dan 33 Tahun 2004.

Pengertian keuangan daerah menurut Keputusan Menteri Dalam Negeri Nomor 29 Tahun 2002 (yang sekarang berubah menjadi Permendagri Nomor 13 Tahun 2006) tentang Pedoman Pengurusan, Pertanggungjawaban dan Pengawasan Keuangan Daerah Serta Tata Cara Penyusunan Anggaran Pendapatan Belanja Daerah (APBD) adalah Semua hak dan kewajiban daerah dalam rangka penyelenggaraan pemerintah daerah yang dapat dinilai dengan uang termaksud didalamnya segala bentuk kekayaan yang berhubungan dengan hak dan kewajiban daerah, dalam kerangka anggaran pendapatan dan belanja daerah.

\section{Dalam}

Undang-undang

pemerintahan Daerah, disebutkan bahwa sumber penerimaan daerah dalam pelaksanaan desentralisasi terdiri atas pendapatan daerah dalam pelaksanaan desentralisasi terdiri atas pendapatan daerah dan pembiayaan. Pembiayaan dapat bersumber dari sisa lebih perhitungan anggaran daerah, penerimaan pinjaman daerah, dana cadangan daerah, dan hasil penjualan kekayaan daerah yang disumbangkan.

Dana perimbangan yaitu dana yang bersumber dari APBN yang dialokasikan kepada daerah untuk mendanai kebutuhan daerah dalam pelaksanaan desentralisasi (otonomi daerah). ${ }^{47}$

Dengan demikian Dana Perimbangan merupakan sumber pendapatan daerah yang berasal dari APBN untuk mendukung pelaksanaan kewenangan pemerintah daerah dalam mencapai tujuan pemberian otonomi kepada daerah, yaitu terutama peningkatan pelayanan dan kesejahteraan masyarakat yang semakin baik.

Sebagaimana pembahasan kita mengenai alokasi dana desa bahwa salah satu dari sumber pendapatan Desa adalah adanya bagian dari dana perimbangan keuangan pusat dan daerah yang diterima oleh kabupaten/kota diperuntukkan bagi Desa dengan jumlah paling sedikit $10 \%$ (sepuluh per seratus) dan dibagi secara proporsional pada masing-masing Desa yang disebut ADD.

\section{Otonomi Desa}

Secara etimologi kata desa berasal dari bahasa Sansekerta, deca yang berarti tanah air, tanah asal, atau tanah kelahiran. Desa adalah kesatuan masyarakat hukum yang memiliki kewenangan untuk mengurus rumah tangganya sendiri berdasarkan hak asal-usul dan adat istiadat yang diakui dalam Pemerintahan Nasional dan berada di Daerah Kabupaten.

Berbagai penjelasan tentang otonomi telah dijelaskan dalam pembahasan sebelumnya, hal tersebut tidak jauh berbeda dengan otonomi desa. Ndraha menyatakan bahwa otonomi merupakan hak bawaan suatu masyarakat, bukan harian pemerintah. Dimana Hak adalah bagian intergral kedaulatan, sedangkan Kewenangan bagian integral dari kekuasaan.posisi otonomi desa adalah hak bawaan. ${ }^{48}$

Desa secara historis merupakan cikal bakal terbentuknya masyarakat politik dan pemerintahan di Indonesia jauh sebelum Negara ini terbentuk. Struktur social sejenis desa, masyarakat adat dan lain sebagainya telah menjadi institusi sosial yang mempunyai posisi sangat penting, desa sebagai institusi otonom dengan otonomi asli, dia mempertahankan tradisi, adat istiadat, dan kearifan lokalnya masing-masing. Hal ini ditunjukkan dengan tingkat keragaman yang tinggi sehingga desa merupakan miniatur dari wujud bangsa yang paling kongkret.

Menurut UU nomor 32 tahun 2004, yang dimaksud dengan Desa adalah sebagai berikut Desa atau yang disebut nama lain, selanjutnya disebut desa, adalah kesatuan masyarakat hukum yang

\footnotetext{
${ }^{48}$ Azam Awang, Op.Cit, Hal. 53. 
memiliki batas-batas wilayah yang berwenang untuk mengatur dan mengurus kepentingan masyarakat setempat, berdasarkan asal-usul dan adat istiadat setempat yang diakui dan/ dibentuk dalam sistem pemerintahan nasional dan berada di kabupaten/ kota, sebagaimana dimaksud dalam UUD Negara republic Indonesia tahun 1945. Landasan pemikiran dalam pengaturan mengenai desa, adalah keanekaragaman, partisipasi, otonomi asli, demokratisasi dan pemberdayaan masyarakat. $^{49}$

Tujuan pembentukan desa adalah untuk meningkatkan kemampuan penyelenggaraan pemerintahan secara berdaya guna dan berhasil guna dan peningkatan pelayanan terhadap masyarakat sesuai dengan tingkat perkembangan dan kemajuan pembangunan.

Otonomi desa merupakan otonomi asli, bulat, dan utuh serta bukan merupakan pemberian dari pemerintah. Sebaliknya pemerintah berkewajiban menghormati otonomi asli yang dimiliki oleh desa tersebut. Sebagai kesatuan masyarakat hukum yang mempunyai susunan asli berdasarkan hak istimewa, desa dapat melakukan perbuatan hukum baik hukum publik maupun hukum perdata, memiliki kekayaan, harta benda serta dapat dituntut dan menuntut di muka pengadilan.

\section{Pemerintahan Desa}

Pemerintahan Desa merupakan bagian dari Pemerintahan Nasional yang penyelenggaraannya ditujukan pada pedesaan. Pemerintah Desa adalah pelaksana fungsi-fungsi pemerintahan desa yang dilakukan oleh lembaga Pemerintahan Desa. Pemerintah Desa secara histosris dibentuk oleh masyarakat desa dengan memilih beberapa orang anggota masyarakat yang dipercaya dapat mengatur, menata, melayani, memelihara mempertahankan dan melindungi berbagai aspek kehidupan mereka. Aspek kehidupan masyarakat desa biasanya yang utama adalah hukum adat(istiadat) tertulis maupun tidak tertulis,sosial budaya kemasyarakatan, ekonomi pertanian, perkebunan, pemerintahan dan kehidupan masyarakat desa lainnya. Pemerintah Desa merupakan bentuk formalisasi organisasi kelembagaan masyarakat desa. Kehadiran pemerintah desa merupakan pemenuhan kebutuhan dan eksistensi masyarakat desa. ${ }^{50}$

Sebelum lahirnya Undang-Undang No 22 Tahun 2009 tentang Pemerintah Daerah berlaku kebijakan Pemerintah Desa dengan Undang-Undang Pemerintah Desa No. 5 tahun 1979 yang menegaskan bahwa Desa adalah suatu wilayah yang ditempati oleh sejumlah penduduk sebagai kesatuan masyarakat termasuk di dalamnya kesatuan masyarakat huklum yang mempunyai organisasi pemerintahan terendah langsung di bawah camat dan berhak menyelenggarakan rumah tangganya sendiri dalam ikatan Negara Kesatuan Republik Indonesia. ${ }^{51}$

Rumusan tersebut memuat konsep hak untuk menyelenggarakan rumah tangganya sendiri, namun jugs disebutkan bahwa desa merupakan organisasi pemerintahan terendah di bawah camat.

Otonomi bagi pemerintahan desa sebagai perwujudan pelaksanaan asas desentralisasi dalam penyelenggaraan pemerintahan. Dengan adanya otonomi desa, desa memiliki kewenangan untuk mengurus dan kepentingan masyarakat desa setempat sesuai prakarsa sendiri berdasarkan aspirasi masyarakat desa.

Menurut Azam Awang, Desa yang otonom adalah Desa yang mandiri dari tingkat desentralisasi yang diselenggarakan. Semakin tinggi derajat desentralisasi ke Desa maka semakin tinggi tingkat otonomi desa. ${ }^{52}$

\section{Alokasi Dana Desa}

\footnotetext{
${ }^{51}$ Undang-Undang Nomor 5 Tahun1979 Tentang

Pemerintahan Desa

${ }^{52}$ Azam Awang, Op.Cit, hal. 53.
} 
Semenjak berlakunya Undang Undang No. 22 Tahun 1999 yang diperbaharui dengan Undang-undang Nomor 32 Tahun 2004 tentang Pemerintahan Daerah, pemerintah daerah mempunyai kewenangan yang lebih luas dalam pengelolaan daerahnya. Munculnya Undung-Undang tersebut telah merubah pardigma pembangunan dari sentralistik menjadi desentralisasi. Salah satu wujud implementasi Undang-Undang tersebut adalah bahwa pemerintah daerah telah berusaha untuk menggali berbagai potensi yang ada di daerahnya dalam rangka untuk meningkatkan kesejahteraan rakyat. Salah satu bentuk kepedulian pemerintah terhadap pengembangan wilayah pedesaaan adalah adanya anggaran pembangunan secara khusus yang dicantumkan dalam Anggaran Pendapatan dan Belanja Daerah (APBD) untuk pembangunan wilayah pedesaan, yakni dalam bentuk Alokasi Dana Desa (ADD).

Menurut Bayu Suryaninggrat desa merupakan Badan pemerintahan Negara yang terendah yang terdekat yang berhubungan lansung dengan masyarakat, maka dari desalah yang paling benar atau yang mendekati kebenaran atau sesuai dengan kenyataan, hanya desalah yang mengetahui beberapa dan siapa penduduknya, apa mata pencaharian penduduknya, berapa jumlah pengangguran dan sebagainya. ${ }^{53}$

Sedangkan menurut Binarto dalam Sadu Wasistiono yang memandang desa secara geografi mendefinisikan Desa merupakan suatu hasil perwujudan antara kegiatan sekelompok manusia dengan lingkungannya, hasil dari perpaduan itulah suatu wujud penampakan dimuka bumi yang ditimbulkan oleh unsure-unsur fisiografi, faktor ekonomi, politik dan kultural yang saling berinteraksi antara unsur tersebut dan juga dalam hubungan dengan daerah lain. ${ }^{54}$
Desa sebagai ujung tombak pemerintahan dalam hirarki susunan pemerintahan di negara Indonesia juga mengemban amanat otononomi sebagai konsekuensi pelaksanaan otonomi daerah yang mulai diberlakukan semenjak Tahun 1999. Dalam upaya peningkatan peran pemerintahan desa dalam memberikan pelayanan dasar kepada masyarakat dan pemberdayaan masyarakat maka pemerintahan desa perlu didukung dana dalam melaksanakan tugas-tugasnya baik di bidang pemerintahan maupun bidang pembangunan.

Desa mempunyai hak untuk memperoleh bagi hasil pajak daerah dan retribusi daerah dan bagian dari dana perimbangan keuangan pusat dan daerah yang diterima oleh kabupaten/kota. Bagian perolehan desa dari kabupaten disebut Alokasi Dana Desa (ADD) yang dusalurkan melalui kas desa. Pemberian ADD merupakan wujud pemenuhan hak desa untuk menyelenggarakan otonominya agar tumbuh dan berkembang berdasarkan keanekaragaman, partisipasi, otonomi asli, demokratisasi dan pemberdayaan masyarakat itu sendiri. Dalam hal Alokasi Dana Desa (ADD) di Kabupaten Bone telah diatur dalam Peraturan Daerah Nomor 11 Tahun 2008 tentang Alokasi Dana Desa dengan merujuk pada aturan yang lebih tinggi.

\section{METODE PENELITIAN}

Pendekatan penelitian yang digunakan dalam penelitian ini adalah pendekatan kualitatif. Dengan pendekatan kualitatif diharapkan dapat diungkapkan situasi dan permasalahan yang dihadapi dalam kegiatan Pelaksanaan peraturan daerah ini. Adapun jenis penelitian ini yang digunakan dalam penelitian ini adalah deskriptif. Dengan Jenis penelitian deskriptif yang digunakan pada penelitian

\footnotetext{
${ }^{54}$ Sadu Wasistiono Dan M. Irwan Tahir, Prospek Pembangunan Desa, Fakultas Media, Bandung, 2007, Hal. 8.
}

${ }^{53}$ Bayu Suryaninggrat, Pemerintahan Desa Dan Kelurahan, Aksara Baru, Jakarta,1985, Hal.108. 
ini dimaksudkan untuk memperoleh informasi mengenai pelaksanaan peraturan daerah nomor 11 tahun 2008 tentang alokasi dana desa di kecamatan libureng.

Berdasarkan sumbernya, jenis data dibagi menjadi dua yaitu data primer dan data sekunder. Data Primer, yakni data yang diperoleh langsung dari para narasumber berupa informasi di lapangan, yang meliputi pelaksanaan Alokasi Dana Desa dengan faktor-faktor yang mempengaruhi. Data Sekunder, yakni data yang diperoleh melalui catatan-catatan yang berkaitan erat dengan permasalahan yang diteliti, diantaranya data dari segala kegiatan yang berkaitan dengan proses pelaksanaan Alokasi Dana Desa serta dokumen-dokumen.

Sumber data berupa kata-kata dalam penelitian ini diperoleh peneliti malalui wawancara dengan orang-orang yang dapat dipercaya kebenaran informasinya, seperti kepala desa dan ketua BPD. Data ini dicatat secara tertulis setiap kali peneliti melakukan wawancara di lapangan.

Instrument yang digunakan dalam penelitian ini adalah peneliti sendiri, dengan alat bantu berupa pedoman wawancara, yaitu sejumlah pertanyaan terstruktur atau tidak terstruktur apabila dianggap perlu untuk memperoleh keterangan yang diperlukan dari Narasumber.

Teknik pengumpulan data dalam penelitian ini adalah dengan menggunakan metode:

\section{Wawancara} wawancara guna untuk memperoleh penjelasan yang rinci dan mendalam mengenai pelaksanaan kebijakan dan faktor-faktor yang mempengaruhi pelaksanaan Alokasi Dana Desa di wilayah Kecamatan Libureng Kabupaten Bone.

2. Dokumentasi
Dokumentasi digunakan untuk memperoleh data sekunder, yakni dengan cara menelaah dokumen dan kepustakaan yang dikumpulkan dari berbagai dokumen seperti; peraturan perundang-undangan dan dokumen pendukung lainnya yang memuat pendapat para ahli kebijakan sehubungan dengan penelitian.

\section{HASIL PENELITIAN DAN PEMBAHASAN}

\section{HASIL PENELITIAN}

\section{Pelaksanaan Alokasi Dana Desa Di Kecamatan Libureng}

Pelaksaanaan program Alokasi Dana Desa (ADD) di Kecamatan Libureng telah berjalan dengan baik meskipun masih ada kendala yang ditemui dalam pelaksanaannya. Sebagaimana dengan aturan hukum yang berlaku terkhusus Peraturan Daerah Nomor 11 Tahun 2008 tentang Alokasi Dana Desa, ADD bertujuan untuk pemerataan pembangunan dan meningkatkan partisipasi, kesejahteraan serta pelayanan masyarakat desa melalui pembangunan dalam skala desa.

Dalam hal menyusun perencanaan penggunaan ADD di Kecamatan Libureng melibatkan BPD, berdasarkan wawancara dengan narasumber kami dari tiga kepala Desa di Kecamatan Libureng. Kepala Desa Mallinrung mengungkapkan bahwa ya, otomatis dik, karena harus ditanda tangani ketua BPD kalau tidak itu tidak diterima, yang dilibbatkan di situ semua aparat desa mulai ketua BPD, sekertaris desa, bendahara, dan kepala dusun, karena berita acara haris ditanda tangani semua itu. ${ }^{55}$ Kepala Desa Bune mengatakan pula ya, dalam menyususn perencanaan ADD harus melibatkan BPD. ${ }^{56}$ Kepala Desa

\footnotetext{
${ }^{55}$ Satriadi, Kepala Desa Mallinrung ( Wawancara

Tanggal 29 April 2016)

${ }^{56} \mathrm{Hj}$. Herawati, Kepala Desa Bune (Wawancara

Tanggal 3 Mei 2016)
} 
Wanuawaru mengatakan ya, semua lembaga masyarakat dilibatkan semua. ${ }^{57}$

Hal demikian diungkap pula oleh tiga informan dari tiga desa di kecamatan libureng, Ketua BPD desa mallinrung mengatakan ya, Dalam menyusun perencanaan penggunaan ADD Melibatkan BPD karena harus ditanda tangani ketua BPD. ${ }^{58}$

Ungkapan serupa juga dinyatakan dari 2 informan lainnya yakni Dalam menyusun perencanaan penggunaan ADD Meibatkan BPD yakni ketua BPD desa bune dan wanuawaru. ${ }^{59}$

Berdasarkan hasil wawancara diatas dari berbagai narasumber dapat ditarik kesimpulan bahwa semua Desa di Kecamatan Laibureng telah melibatkan BPD dalam menyusun perencanaan penggunaan ADD.

Wawancara diatas menunjukkan pula bahwa pelaksanaan Perda Nomor 11 Tahun 2008 tentang Alokasi Dana Desa telah berjalan optimal, pemerintahan Desa telah menjalankan tugasnya dimana Kepala Desa telah mengkordinasikan musyawarah antara Pemerintah Desa, BPD, dan Elemen Desa mengenai rencana penggunaan ADD.

Dalam hal Perencanaan pelaksanaan ADD di Kecamatan Libureng telah berjalan sesuai dengan Peraturan perundang-undangan, akan tetapi perencanaan di kecamatan libureng ini agak terlambat, Sebagaimana diungkapakan Kepala Desa Mallinrung bahwa Perencanaan ADD dalam penyusunannya dikecamatan libureng ini dari 18 desa 2 kelurahan, saya yang pertama selesai seluruh berkas yang mau di masukkan di keuangan. Dalam langkah awalnya itu memang agak terhambat agak terlambat, seharusnya anggaran itu dek sudah cair maret, tapi karena aturannya terlalu rumit, tiap tahun selalu berubah ubah, makanya terlambat. Di bone itu kalau tidak salah baru 10 desa yang cair anggarannya, kalau tidak salah, entah kemarin atau hari ini baru tertambah. ${ }^{60}$

Kepala Desa Bune mengatakan bahwa Dalam perencanaan ADD di desa ini dilakukan dengan musyawarah dusun kemudian dilakukan musrembang desa kemudian membuat RPJMDes, untuk menyusun itu dilakukan musyawarah desa baru dicover semua. Setelah itu dibuat rencana kegiatan skala proritas, Artinya dalam setiap tahun terbatas anggaran sementara program di desa tidak bisa dicover satu persatu. Dalam musyawarah dilakukan pembahasan apa yang akan di kerjakan. ${ }^{61}$

Kepala Desa Wanuawaru mengatakan bahwa perencanaan ADD di desa ini dibuat rencana musrembang dusun terus musrembang desa kemudian musrembang kecamatan. Setelah musrembang itu baru dilakukan rencana pembangunan. Setelah semua ini terlaksana baru di tentukan apa yang akan dikerjan. Setelah itu di buat rencana RPJMDes, rencana RPJMDes jangkah panjang untuk 5 Tahun kedepan. Kita buat seperti itu, jadi Semua usulan yang ada musrembang di masukkan di RPJMDes artinya semua usulan yang ada di desa, pokoknya berapa-berapa usulan yang ada di desa dimasukkan karena semua mau dikerja dimasukkan disitu. Setelah itu di bentuk tim penyusun RPJMDes kemudian isi dari RPJMDes tersebut memuat seluruh daftar usulan atau permasalahan yang ada di desa. Di buat satu kali 5 Tahun. Setelah jadi RPJMDes, di pilah-pilah yang mana kira-kira kegiatan yang proritas yang mana mendesak, ditentukan dan di tentukanmi dulu. Ada istilah RKPDes. Dari RPJMDes dituangkan kedalam RKPDes, isi RKPDes

\footnotetext{
${ }^{57} \mathrm{Hj}$. Andi Nurjannah, Kepala Desa Wanuawaru ( Wawancara Tanggal 5 Mei 2016)

${ }^{58}$ Kadir, Ketua BPD Desa Mallinrung (wawancara Tanggal 1 Mei 2016)

${ }^{59}$ Pardin, Ketua BPD Bune (Wawancara Tanggal 7 Mei 2016) dan Bakri, Ketua BPD Desa Wanuawaru (

Wawancara Tanggal 9 Mei 2016)
}

\footnotetext{
${ }^{60}$ Satriadi, Kepala Desa Mallinrung ( Wawancara Tanggal 29 April 2016)

${ }^{61} \mathrm{Hj}$. Herawati, Kepala Desa Bune (Wawancara Tanggal 3 Mei 2016)
} 
memuat rencana kerja tahunan. Apa-apa yang akan kita kerjakan tahun itu, disitu termuat didalam RKPDes. ${ }^{62}$

Berdasarkan hasil wawancara diatas dari berbagai narasumber dapat ditarik kesimpulan bahwa semua Desa di Kecamatan Libureng telah melaksanakan rancangan pengelolaan $\mathrm{ADD}$ di dalam APBDes selanjutnya di tetapkan menjadi Perdes, APBDes yang disusun berdasarkan RKP Desa dan ditetapkan dengan Peraturan Desa. Dan Wawancara diatas menunjukkan pula bahwa pelaksanaan Perda Nomor 11 Tahun 2008 tentang Alokasi Dana Desa telah berjalan dengan baik, pemerintahan Desa telah menjalankan tugasnya dimana Kepala Desa telah mengkordinasikan musyawarah antara Pemerintah Desa, BPD, dan Elemen Desa mengenai rencana penggunaan ADD dan menyusun rencana Peraturan Desa tentang APBDesa setelah disetujui bersama oleh BPD dan Kepala Desa dan ditetapkan menjadi Peraturan Desa (Perdes) sebagaimana tertuang dalam Pasal (5) tentang tugas Kepala Desa dan BPD.

Dalam menyusun jadwal rencana pencairan dana di kecamatan libureng dilakukan dengan melengkapi berkas, sebagaimana diungkapkan tiga narasumber dari tiga desa di kecamatan libureng. Kepala Desa Mallinrung Mengatakan bahwa Untuk pecairan harus lengkap semua berkas, karena ada beberapa yang mau di masukkan di keuangan baru bisa pencairan diantaranya RPJMDes, APBDes, RKPDes, dan RAPBDes. Apabila salah satunya tidak ada maka tidak bisa. ${ }^{63}$

Kepala Desa Bune Mengatakan untuk pencairan harus lengkap semua berkas. Seperti RPJMDes, APBDes, RKPDes,dan RAPBDes. ${ }^{64}$

Kepala Desa Wanuawaru Mengatakan bMekanisme pencairan dananya itu di buat dalam APBDes isitu di muat apa yang mau dialokasikan dana. Setelah selesai APBDes masuk di pencairannya dengan melengkapi dokumen sesuai dengan permintaan. ${ }^{65}$

Berdasarkan hasil wawancara diatas dari berbagai narasumber dapat ditarik kesimpulan bahwa semua Desa di Kecamatan Libureng telah melaksanakan Perda Nomor 11 Tahun 2008 tentang Alokasi Dana Desa telah berjalan optimal, pemerintahan Desa telah menjalankan tugasnya mengenai rencana pencairan ADD.

Dalam hal pelaksanaan ADD sebagaimana Peraturan Daerah Nomor 11 tahun 2008 tentang Alokasi Dana Desa menentukan bahwa $30 \%$ dana ADD digunakan untuk biaya operasional pemerintahan Desa dan $70 \%$ dana ADD digunakan untuk kegiatan pemberdayaan masyarakat. Oleh karena itu beberapa desa telah membuat APBDes yang memuat penggunaan dana ADD, dalam hal pelaksanaan aturan tersebut Kepala Desa Mallinrung Mengungkapkan bahwa hal tersebut terlaksana, Penggunaan ADD dengan ketentuan 30\% digunakan untuk biaya operasional desa dan BPD dan $70 \%$ digunakan untuk kegiatan pemberdayaan masyarakat. ${ }^{66}$ Hal yang serupa di ungkapkan pula kepala desa bune dan wanuawaru.

Berdasarkan hasil wawancara dengan narasumber diatas menunjukkan jawaban yang relatif sama dimana telah mengadakan peruntukan dana ADD sebagaimana yang diatur dalam Pasal 4 angka (2) Peraturan daerah Nomor 11 tahun 2008 tentang ADD. jadi dapat disimpulkan bahwa keseluruhan Desa di Kecamatan Libureng telah menempatkan fungsi dan pembagian dana ADD sesuai pada tempatnya berdasarkan aturan yang berlaku.

\footnotetext{
${ }^{62} \mathrm{Hj}$. Andi Nurjannah, Kepala Desa Wanuawaru ( Wawancara Tanggal 5 Mei 2016)

${ }^{63}$ Satriadi, Kepala Desa Mallinrung ( Wawancara Tanggal 29 April 2016)

${ }^{64} \mathrm{Hj}$. Herawati, Kepala Desa Bune (Wawancara

Tanggal 3 Mei 2016)
}

\footnotetext{
${ }^{65} \mathrm{Hj}$. Andi Nurjannah, Kepala Desa Wanuawaru ( Wawancara Tanggal 5 Mei 2016)

${ }^{66}$ Satriadi, Kepala Desa Mallinrung ( Wawancara Tanggal 29 April 2016)
} 
Dalam hal hasil dari pelaksanaan kegiatan yang dibiayai dari ADD tahun 2015 di kecamatan libureng, Kepala Desa Mallinrung Mengatakan hasil dari penggunaan ADD diantaranya Pengerasan perintis jalan yang berlokasi di cenranae, Pembangunan irigasi. Rata rata di tahun 2015 pembangunan irigasi yang di kerjakan. ${ }^{67}$

Kepala Desa Bune Mengatakan Hasil penggunaan ADD ada 2 macam yang pertama itu secara fisik diantaranya jembatan tani, perintisan jalan, dan rabat beton. Dan yang kedua nonfisik diantaranya pembinaan PKL, Pembinaan posyandu, dan pembinaan pemuda dan olahraga. ${ }^{68}$

Kepala Desa Wanuawaru Mengatakan Adapun Hasil dari penggunaan ADD diantaranya perintisan jalan dan pembangunan poskesdes. ${ }^{69}$

Berdasarkan hasil wawancara diatas dapat disimpulkan bahwa penggunaan ADD di kecamatan libureng sudah dilaksanakan dengan baik.

Berdasarakan wawancara dengan keseluruhan narasumber, dapat disimpulkan bahwa pelaksaanaan Peraturan Daerah Nomor 11 Tahun 2008 tentang Alokasi Dana Desa penerapannya dapat terlaksanakan di Kecamatan Libureng diliat dari proses pembinaan, perencanaan, peranan, pembagian dan penggunaan ADD yang dilakukan instansi terkait dalam pelakasanaa ADD di Kecamatan Libureng yakni Pemerintah Kecamatan selaku Tim Pendamping Kecamatan dan pemerintah Desa selaku Tim Pelaksana Tingkat Desa.

\section{Hambatan Pelaksanaan Alokasi Dana Desa}

Secara umum pelaksanaan Alokasi Dana Desa (ADD) telah berjalan dengan baik sebagaimana aturan perundangundangan. Namun demikian pelaksanaan kebijakan ADD di Kecamatan Libureng masih terdapat kendala. Hal tersebut dapat diketahui melalui berbagai pendapat yang dikemukankan oleh para narasumber.

Kepala Desa Mallinrung mengungkapkan permasalahan yang mereka dapatkan dalam proses pelaksanaan ADD di Desanya, sebagaimana dalam pelaksanaanya beliau mengatakan hambatanyan membuat laporan pertanggungjawaban, tapi itu sebenarnya tidak terlalu rumit. Persoalannya itu aturan selalu berubah. Tapi Alhamdulillah selesai juga. Persoalan pekerjaan tidak ada hambatan. ${ }^{70}$

Sementara Kepala Desa Bune mengungkapkan permasalahan yang mereka dapatkan dalam proses pelaksanaan ADD di Desanya, sebagaimana dalam pelaksanaanya beliau mengatakan hambatannya keadaan lingkungan desa, yang kadang hujan yang membuat terhambatnya pembangunan yang di kerjakan. ${ }^{71}$

Hal yang diungkapkan oleh Kepala Desa mallinrung dan bune sangat berbeda dengan penyampaian kepala desa wanuawaru beliau mengatakan Tidak ada, karena semua ada undang-undang, terus ada bimbingan dari atas dan pihak-pihak yang terkait. ${ }^{72}$

Dari hasil wawancara diatas dapat disimpulkan bahwa kendala utama pelaksanaan ADD yaitu cuaca yang tidak menentu dan pembuatan laporan pertanggung jawaban.

Dalam mengatasi permasalahan yang mereka dapatkan dalam proses pelaksanaan ADD di Desanya, Kepala Desa Mallinrung Mengatakan Koordinasi

\footnotetext{
${ }^{67}$ Satriadi, Kepala Desa Mallinrung ( Wawancara

Tanggal 29 April 2016)

${ }^{68} \mathrm{Hj}$. Herawati, Kepala Desa Bune (Wawancara Tanggal 3 Mei 2016)

${ }^{69} \mathrm{Hj}$. Andi Nurjannah, Kepala Desa Wanuawaru ( Wawancara Tanggal 5 Mei 2016)
}

\footnotetext{
70 Satriadi, Kepala Desa Mallinrung ( Wawancara Tanggal 29 April 2016)

${ }^{71} \mathrm{Hj}$. Herawati, Kepala Desa Bune (Wawancara Tanggal 3 Mei 2016)

${ }^{72} \mathrm{Hj}$. Andi Nurjannah, Kepala Desa Wanuawaru ( Wawancara Tanggal 5 Mei 2016)
} 
dengan aparat desa. Mulai dengan sekertaris desa, bendahara dan BPD. ${ }^{73}$

Kepala Desa Bune

MengatakanDengan melihat kondisi yang ada. ${ }^{74}$ Sementara Kepala Desa Wanuawaru Mengatakan konsultasi dengan pihak PEMDES.

Berdasarkan hasil wawancara diatas dapat disimpulkan bahwa setiap permasalahan yang mereka dapatkan dalam proses pelaksanaan ADD di Desanya dapat di selesaikannya.

Dalam pembagian ADD Tahun anggaran 2015 memakai sistem pembagian yang berbeda dengan tahun sebelumnya, Kepala Desa Mallinrung Mengatakan Ya, jelas berbeda karena setiap tahun aturan selalu berubah-ubah. ${ }^{75}$

Hal yang diungkapkan oleh Kepala Desa mallinrung sangat berbeda dengan yang diungkapkan kepala desa bune dan wanuawaru. Kepala Desa Bune Mengatakan Tidak, aturannya sama saja. ${ }^{76}$ Kepala Desa Wanuawaru Mengatakan Tidak ada berbeda. ${ }^{77}$

Berdasarkan hasil wawancara diatas dapat disimpulkan bahwa pembagian ADD tahun 2015 dengan tahun sebelumnya di kecamatan libureng, ada desa yang memakai sistem pembagian yang sama dan ada yang berbeda.

Dalam pembinaan atas penggunaan ADD dilakukan oleh tim Pembina tingkat kecamatan, Kepala Desa Mallinrung Mengatakan Ada, karena kalau tidak ada pembinaan pasti tidak akan selesai. ${ }^{78}$ Kepala Desa Bune Mengatakan Ya,ada pembinaan. ${ }^{79}$ Kepala Desa Wanuawaru Mengatakan Iya,selalu seperti itu. Ada memang pembinaan dari kabupaten, dari kecamatan. Karena begitu kita dalam bekerja harus selalu berkonsultasi. ${ }^{80}$
Berdasarkan hasil wawancara diatas dapat ditarik kesimpulan bahwa semua Desa di Kecamatan Libureng telah mendapat pembinaan atas penggunaan ADD yang dilakukan oleh tim Pembina tingkat kabupaten dan tin Pembina tingkat kecamatan.

Wawancara diatas menunjukkan pula bahwa pelaksanaan Perda Nomor 11 Tahun 2008 tentang Alokasi Dana Desa telah berjalan dengan baik, pemerintahan telah menjalankan tugasnya dimana Pembinaan atas penggunaan ADD dilakukan oleh Tim Pembina Tingkat Kabupaten dan Tim Pembina Tingkat Kecamatan, sebagaimana tertuang dalam Pasal (7) tentang pembinaan.

\section{PEMBAHASAN}

\section{Pelaksanaan ADD Di Kecamatam Libureng}

Alokasi Dana Desa yang selanjutnya disingkat ADD adalah dana yang dialokasikan oleh pemerintah kabupaten untuk desa yang bersumber dari bagian perimbangan keuangan pusat yang diterima oleh kabupaten.

Pembangunan desa sebagai bagian integral dari pembangunan daerah dilaksanakan berdasarkan prinsip-prinsip otonomi desa dan pengaturan sumber daya daerah yang memberikan kesempatan bagi peningkatan demokrasi dan kinerja desa untuk meningkatkan kesejahteraan masyarakat. Penyelenggaraan pemerintah desa sebagai sub sistem pemerintah daerah dimaksud untuk meningkatkan dayaguna dan hasil guna pemerintahan dan pelayanan masyarakat sebagai level pemerintahan terdepan desa mempunyai kewenangan dan tanggung jawab mengatur dan mengurus rumah tangganya sendiri

\footnotetext{
${ }^{77} \mathrm{Hj}$. Andi Nurjannah, Kepala Desa Wanuawaru ( Wawancara Tanggal 5 Mei 2016)

${ }^{78}$ Satriadi, Kepala Desa Mallinrung ( Wawancara Tanggal 29 April 2016)

${ }^{79} \mathrm{Hj}$. Herawati, Kepala Desa Bune (Wawancara Tanggal 3 Mei 2016)

${ }^{80} \mathrm{Hj}$. Andi Nurjannah, Kepala Desa Wanuawaru ( Wawancara Tanggal 5 Mei 2016)
} 
berdasarkan prinsip-prinsip keterbukaan, partisipasi masyarakat, dan pertanggung jawaban kepada masyarakat.

\section{Untuk}

mendukung

penyelenggaraan otonomi desa diperlukan sumber pembiayaan. Oleh karena itu pemerintah daerah menganggap perlu memberikan bantuan dana kepada desa dalam bentuk perimbangan keuangan yang tujuan pokoknya antara lain:

a. Memberdayakan meningkatkan

dan perekonomian desa;

b. Menciptakan system pembiayaan desa yang adil, profesional, rasional, transparan,partisipatif, bertanggung jawab, dan pasti;

c. Menjadi acuan dalam alokasi penerimaan daerah bagi desa;

d. Menjadi pedoman pokok tentang keuangan desa;

Dalam Pelaksaanaan program Alokasi Dana Desa (ADD) di Kecamatan Libureng telah berjalan dengan baik meskipun masih ada kendala yang ditemui dalam pelaksanaannya. Sebagaimana dengan aturan hukum yang berlaku terkhusus Peraturan Daerah Nomor 11 Tahun 2008 tentang Alokasi Dana Desa, ADD bertujuan untuk pemerataan pembangunan dan meningkatkan partisipasi, kesejahteraan serta pelayanan masyarakat desa melalui pembangunan dalam skala desa.

Adapun alur aspirasi masyarakat desa yaitu diawali dari musyawarah Dusun yang dilanjutkan ke musyawarah Desa yang dihadiri oleh tokoh-tokoh masyarakat, tokoh Agama, RT / RW, Pemerintah Desa beserta BPD dalam rangka penggalian gagasan. Dari penggalian gagasan tersebut dapat diketahui permasalahan yang ada di Desa dan kebutuhan apa yang diperlukan oleh masyarakat sehingga aspirasi seluruh lapisan masyarakat bisa tertampung. Sebagai wakil dari masyarakat Lembaga Desa berperan aktif membantu pemerintah Desa dalam menggerakkan program Pembangunan. Pemerintah Desa beserta
Lembaga Desa merumuskan program Pembangunan Desa, dalam hal ini menyusun Pembangunan apa yang sifatnya mendesak dan harus dilakukan dengan segera dalam arti menyusun skala prioritas. Dalam perencanaan penggunaan ADD di kecamatan libureng dilakukan dengan musrembang dusun terus musrembang desa kemudian musrembang kecamatan. Setelah musrembang itu baru dilakukan rencana pembangunan. Setelah semua ini terlaksana baru di tentukan apa yang akan dikerjan. Setelah itu di buat RPJMDes. Jadi Semua usulan yang ada musrembang di masukkan di RPJMDes. Setelah itu di bentuk tim penyusun RPJMDes kemudian isi dari RPJMDes tersebut memuat seluruh daftar usulan atau permasalahan yang ada di desa. Setelah jadi RPJMDes, di pilah-pilah yang mana kira-kira kegiatan yang mendesak dalam arti skala prioritas. Dari RPJMDes dituangkan kedalam RKPDes, isi RKPDes memuat rencana kerja tahunan. Apa-apa yang akan kita kerjakan tahun itu, disitu termuat didalam RKPDes.

Sebagai satu kesatuan masyarakat Desa mempunyai hak untuk memperoleh Alokasi Dana Desa (ADD) yang di salurkan melalui kas desa. Pemberian ADD merupakan wujud pemenuhan hak desa untuk menyelenggarakan otonominya agar tumbuh dan berkembang berdasarkan keanekaragaman, partisipasi, otonomi asli, demokratisasi dan pemberdayaan masyarakat itu sendiri.

\section{Hambatan Dalam Pelaksanaan ADD Di Kecamatan Libureng}

Dalam upaya peningkatan peran pemerintahan desa dalam memberikan pelayanan dasar kepada masyarakat dan pemberdayaan masyarakat maka pemerintahan desa perlu didukung dana dalam melaksanakan tugas-tugasnya baik di bidang pemerintahan maupun bidang pembangunan.

Secara umum pelaksanaan Alokasi Dana Desa (ADD) telah berjalan dengan baik sebagaimana aturan perundang- 
undangan. Namun demikian pelaksanaan kebijakan ADD di Kecamatan Libureng masih terdapat kendala. Setiap kendala yang mereka dapatkan dalam proses pelaksanaan ADD di Desanya dapat di selesaikannya dengan adanya bimbingan dari pihak-pihak yang terkait yakni pendamping tingkat kecamatan dan pendamping tingkat desa.

\section{PENUTUP}

\section{Kesimpulan}

Berdasarkan uraian hasil penelitian dan pembahasan yang telah diuraikan pada bab sebelumnya, maka dalam penulisan skripsi ini dapat ditarik kesimpulan sebagai berikut : (1) Pelaksanaan Peraturan Daerah Nomor 11 tahun 2008 tentang Alokasi Dana Desa (ADD) di Kecamatan Libureng Kabupaten Bone berjalan cukup Baik. Hal ini dapat terlihat dari tahap perencanaan berupa aparat Pemerintahan telah melakukan musyawarah dalam hal perencanaan ADD, dan melakukan pembuatan RPJMDes, serta pembuatan RKPDes Sebagaimana Peraturan daerah tentang ADD yang dapat menjadi arahan bagi Tim Pelaksana Desa dalam menjalankan ADD baik dalam hal pengalokasian dana serta tujuan penggunaan dana. (2) Beberapa hambatan dalam pelaksanaan ADD yang ditemui yakni pembuatan laporan pertanggungjawaban dan kondisi cuaca di lingkungan desa seperti musim hujan yang dapat menghambat pelaksanaan pembangunan yang dilakukan. Setiap permasalahan yang mereka dapatkan dalam proses pelaksanaan ADD di Desanya dapat di selesaikannya dengan adanya bimbingan dan konsultasi dengan pihal-pihak yang terkait seperti tim Pembina tingkat kabupaten dan tim Pembina tingkat kecamatan.

\section{Saran}

Adapun saran-saran dari hasil penelitian ini diantaranya : (1) Perlu adanya sosialisasi terhadap kebijakan
ADD diberikan kepada masyarakat luas sehingga setelah memahami kebijakan ADD, masyarakat juga akan lebih mudah untuk diajak berpartisipasi dalam pelaksanaan ADD, dan ikut mengawasi jalannya ADD sesuai dengan ketentuan yang ada. (2) Para pelaksana ADD diberikan peningkatan pengetahuan melalui pendidikan dan latihan, khususnya yang menyangkut pengelolaan keuangan desa. Sedangkan untuk mempercepat pencairan dana ADD pemrintah Desa diharapkan mampu menyusun rancangan penggunaan ADD sebagaimana tujuannnya sehingga mempermudah perivikasi dari Tim Pendamping Kecamatan.

\section{DAFTAR PUSTAKA}

Jimly Asshiddiqie. 2010. Perihal Undangundang, Jakarta : Rajawali Pers

Azam Awang. 2010. Implementasi Pemberdayaan Pemerintah Desa, Yogyakarta : Pustaka Pelajar

Bayu Suryaninggrat. 1985. Pemerintahan Desa Dan Kelurahan, Jakarta : Aksara Baru

Budi Winarno. 2002. Teori dan Proses Kebijakan public. Yokyakarta : Media Pressindo

Jeddawi Murtir. 2006. Hukum Pemerintahan Daerah, Yogyakarta : UII Pers

Nasution. 2012. Metode Reseach (penelitian ilmih), Jakarta : Bumi Aksara

Ridwan. 2009. Hukum Administrasi di Daerah, Yogyakarta : FH UII Press

Rozali Abdullah. 2011. Pelaksanaan Otonomi Luas: Dengan Pemilihan Kepala Daerah Secara Langsung. Jakarta : Rajawali Pers

Sadu Wasistiono, M. Irwan Tahir. 2007. Prospek Pembangunan Desa. Bandung : Fakultas Media 
Siswanto Sunarno. 2006. Hukum Pemerintahan Daerah. Jakarta : Sinar Grafika

Solihin Abdul Wahab. 2008. Analisis Kebijaksanaan: Dari Formulasi Ke Implementasi Kebijaksanaan Negara, Jakarta : Bumi Aksara

Undang - undang Nomor 32 Tahun 2004 tentang Pemerintahan Daerah

Undang - undang Nomor 33 Tahun 2004 tentang Perimbangan Keuangan antara Pemerintah Pusat dan Pemerintahan Daerah

Peraturan Pemerintah Nomor 72 Tahun 2005 tentang Desa

Peraturan Daerah Nomor 11 Tahun 2008 tentang Alokasi Dana Desa.

Undang-Undang Nomor 5 Tahun1979 Tentang Pemerintahan Desa

Undang-Undang Nomor 6 Tahun 2014 tentang Desa. 